\title{
LÍNGUA E CULTURA: NOMES DE CIDADES DO ESTADO DE ALAGOAS
}

\section{LANGUAGE AND CULTURE: CITY NAMES IN THE STATE OF ALAGOAS}

\author{
Pedro Antonio Gomes de Melo"
}

Resumo: Este artigo se propõe fazer uma reflexão sobre os nomes próprios individuais designativos de cidades do Estado de Alagoas, à luz dos estudos onomásticos, a partir de uma descrição-crítica dos antropotopônimos - topônimos relativos aos nomes próprios de pessoa - e axiotopônimos - topônimos relativos aos títulos e dignidades que acompanham nomes próprios de pessoa - registrados na Toponímia Municipal Alagoana. As análises revelaram que nesse léxico toponímico, há uma preferência do nomeador para eleição dos antropotopônimos, em detrimento dos axiotopônimos no ato de nomear cidades no Estado. E ainda, que o poder político-econômico determina a escolha dos nomes, funcionando como fator influenciador e/ou condicionador de motivação toponímica nos designativos de cidades do Estado.

Palavras-chave: Léxico; Onomástica; Antropotopônimo; Axiotopônimo; Cultura.

ABSTRACT: This paper reflects on individual city names in the State of Alagoas, in the light of onomastic studies, from a critical description of anthroponyms - toponyms of proper names for people - and axiotoponyms, which are toponyms relative to the titles used with people's names and registered at the Municipal Toponym of Alagoas. The analysis revealed that in this toponym lexicon, there is a preference for the name giver to select the anthrotoponyms over axiotoponyms when giving names to cities in Alagoas. Another aspect revealed is that the economical political power determines the choice of names, acting as an influencing and/or conditioning toponym motivational factor of city names in the state.

KeYwords: Lexicon; Onomastics; Anthrotoponym; Axiotoponym; Culture.

\footnotetext{
" Mestre em Letras pela Universidade Federal de Alagoas, professor assistente na Universidade estadual de Alagoas, petrus2207@ibest.com.br
} 


\section{CONSIDERAÇÕES INICIAIS}

A prática de nomear lugares - atividade eminentemente humana - evidencia os efeitos da sociedade sobre o linguístico e a maneira pela qual o mundo social nele se representa, sobretudo em seu nível lexical, refletindo o modo de ver a realidade e a forma como seus membros organizam o mundo que os rodeia.

As pesquisas toponímicas, atualmente, revelam ser muito mais que uma área de investigação que trata, apenas, da questão de nomear lugares, esses estudos exercem vínculos com as etnias, com as denominações das sociedades de todos os tempos, com a cultura de cada lugar e influências internas e externas que as localidades sofrem e/ ou exercem sobre os denominadores.

Nesse sentido, nosso foco é refletir sobre a relação simbólica entre língua e cultura presente em nomes próprios individuais designativos de cidades do Estado de Alagoas, à luz dos estudos onomásticos, a partir de uma descrição-crítica dos antropotopônimos - topônimos relativos aos nomes próprios de pessoa, sobrenomes, prenomes ou apelidos de família - e axiotopônimos - topônimos relativos aos títulos que acompanham estes nomes próprios.

Falar sobre estes designativos é retratar a história sócio-cultural da constituição do léxico onomástico-toponímico municipal do Estado de Alagoas, na medida em que revelam características ideológicas, fatos políticos, culturais e históricos, como também, mostrar os fundamentos do nome próprio em nossa civilização. Segundo Seabra (2006, p. 7): Datam da antiguidade as primeiras reflexões sobre a natureza do nome. Apesar desta constatação, o estudo do nome ou do léxico é sempre um tema atual, de grande multiplicidade, uma vez que congrega o linguístico e o extralinguístico.

É importante não confundirmos o nome do município com o município propriamente dito, em outras palavras "o topônimo não é o lugar em si, mas uma de suas representações, carregando em sua estrutura sêmica elementos da língua, da cultura, da época de sua formação, enfim, do homem denominador" (CARVALHINHOS, 2009, p. 83).

Sendo assim, os topônimos podem perpetuar aspectos históricos e ideológicos de uma comunidade. Logo, observar intersecções línguo-culturais na Onomástica é perceber, pois, como determinados aspectos culturais de um grupo se imprimem nestes designativos.

Sob essa perspectiva, investigamos neste artigo os antropotopônimos e axiotopônimos identificados no léxico onomástico-toponímico municipal do Estado de Alagoas, buscando viabilizar a compreensão da inter-relação língua-cultura desse grupo sócio-linguístico-cultural alagoano.

1. O LÉXICO TOPONÍMICO: OS ANTROPOTÔNIMOS E AXIOTOPÔNIMOS

A Toponímia - do ponto de vista linguístico-pode ser compreendida como um recorte lexical de uma língua. Trata-se de um ramo da Onomástica (do grego antigo ỏvo $\mu \alpha \sigma \tau 1 \kappa \eta ́$, ato de nomear) e possui como eixo central de seus estudos o signo toponímico.

Os estudos toponomásticos se vincularam aos contextos tanto linguísticos como 
socioculturais, ocupando-se "do estudo integral, no espaço e no tempo, dos aspectos: geohistóricos, socioeconômicos e antropolinguísticos que permitiram e permitem que um nome de lugar se origine e subsista" (SALAZAR QUIJADA, 1985, p. 18).

O topônimo é o signo linguístico na função designativa de um espaço geográfico e/ou humano. Nessa função, segundo Dick (1980, p. 290), ele representa "uma projeção aproximativa do real, tornando clara a natureza semântica de seu significado", assim adquirindo "um significado que resume toda a história das relações econômicas, políticas, sociais, materiais e espirituais dos homens que vivem ou viveram no meio denominado (CAMPS IGLESIAS; NOROÑA VILÁ, s.d, p. 11-12)

Os nomes referenciais de lugares se incluem em dois sistemas de classificação: o do léxico geral, modificando-se estruturalmente como os demais lexemas e no léxico específico da ciência onomástica. Dessa forma, o acervo toponímico, como recorte do léxico geral da língua, sofre todas as influências e transformações.

Nas palavras de Katamba (1993, p. 99), o léxico não consiste numa "lista passiva de palavras e de seus significados, mas um lugar cheio de vitalidade em que as regras são usadas ativamente para criar novas palavras". Por conseguinte, compreendemos o léxico onomástico-toponímico "como um indicador línguo-cultural, uma vez que o modo como a língua retrata a visão de mundo de um povo evidencia a inter-relação que se estabelece entre língua, meio ambiente e cultura" (MELO, 2013, p. 162). Assim sendo, os signos toponímicos adquirem valores que transcendem o próprio ato de nomear.

Sob essa perspectiva, cabe aos estudos toponímicos "investigar a significação e a origem dos nomes de lugares e também de estudar suas transformações" (ROSTAING, 1961, p. 7). E ainda, observar questões extralinguísticas de natureza física e antropocultural relacionadas à motivação toponímica, pondo em evidência fatos onomásticos, especialmente aqueles ligados à Toponímia. Conforme postula Dauzat (1926, p. 7), ela "conjugada com a história, indica ou precisa os movimentos antigos dos povos, as migrações, as áreas de colonização, as regiões onde tal ou tal grupo linguístico deixou seus traços".

No léxico toponímico, o elo língua/ mundo fica evidente quando registramos os antropotopônimos e os axiotopônimos, explicando sua origem, evolução e variação em função de local, época, hábitos, costumes e personalidades representados nestes nomes locativos. Esse vínculo antropotoponímico em Alagoas é permeado por relações de poder e autoridade.

Neste contexto, o ato de nomear cidades por meio desses nomes próprios indica que o usuário da língua atribui sentidos aos topônimos pela relação que se estabelece com historicidade, ou seja, pelo saber discursivo que se constitui ao longo do tempo e produz dizeres. Com efeito, a memória discursiva torna possível esse dizer para esse sujeito num dado momento e que representa o eixo de sua constituição. 
Ao tratar sobre questão da escolha de nomes referenciais de acidentes físicos e humanos, Dick (1995), explica-nos que:

a adequação da escolha, que passa pelo crivo da objetividade ou da subjetividade do nomeador, ainda que inconscientemente, será sentida ou pela reação do grupo ou pela análise posterior do linguista, em uma fase posterior, distinta do momento inicial de marcação do lugar ou do batismo da pessoa na compreensão do presente, em sua função pragmática. (DICK, 1995, p. 103)

No caso da toponímia alagoana em decorrência do processo de povoamento e colonização ao qual o Estado foi submetido, há grandes contrastes e diferenças regionais, sociais e linguísticas, constituindo dessa forma uma rede de relações toponímicas em seu léxico.

\section{AnÁlise e Resultados}

Doravante, serão apresentadas as análises dos topônimos aqui estudados. O corpus lexical foi constituído por 14 (catorze) nomes próprios individuais identificadores de municípios alagoanos levantados a partir de consulta bibliográfica junto ao Banco de dados do IBGE na internet, como também, pesquisa documental realizada em documentos oficiais do governo brasileiro, no âmbito local e nacional, que tratavam sobre os municípios do Estado de Alagoas.

Os antropotopônimos e axiotopônimos serão apresentados em fichas lexicográfico-toponímicas adaptadas do modelo de Dick (1990) e distribuídos conforme as mesorregiões nas quais designam municípios alagoanos.

As fichas se revelam necessárias para a interpretação destes nomes próprios individuais, em virtude de conter vários campos conceituais que forneceram informações relevantes sobre cada um dos locativos que constituíram o corpus desta pesquisa.

\subsection{Mesorregião do Agreste Alagoano}

Na Mesorregião do Agreste Alagoano, registramos 4 (quatro) antropotopônimos. A saber: (1) Paulo Jacinto, (2) Minador do Negrão, (3) Girau do Ponciano e (4) Coité do Nóia na função onomástica de nomear de municípios.

\section{OI PAULO JACINTO}

Localização: Mesorregião do Agreste Alagoano; Microrregião de Palmeira dos Índios

Topônimo: Paulo Jacinto; Taxionomia: Antropotopônimo

Etimologia: Composto de origem latina: paulus, $-i$ 'pouco, pequeno' + sm. hyacinticus, 'pedra preciosa'. Estrutura Morfológica: elemento específico composto: morfema lexical paul-+ morfema classificatório vogal temática -o +morfema lexical jancit- + morfema classificatório vogal temática -o

Informações Enciclopédicas: Dois aglomerados humanos iniciais, estabelecidos na região, eram chamados pelas respectivas denominações de Lourenço de Cima e Lourenço de Baixo. O primeiro teve origem em uma capela erigida pelo proprietário, Antônio de Souza Barbosa, em homenagem à 
Nossa Senhora da Conceição. Nem ele nem Lourenço Veiga, pioneiros que deram grande impulso ao povoado, foram escolhidos para dar nome à cidade. Anos depois, já no regime republicano, a localidade passou a chamar Paulo Jacinto, por sugestão da direção da Great Western, em homenagem a Paulo Jacinto Tenório, rico fazendeiro de Quebrangulo que havia doado terras para a passagem da ferrovia.

Fonte: www.wikialagoas.al.org.br

No campo toponomástico, observamos que, no caso (1), a motivação de natureza antropocultural prevaleceu no ato de nomear esse município. Primeiramente com o antropotopônimo Lourenço e posteriormente substituído pelo nome próprio individual atual, ou seja, pelo antropotopônimo Paulo Jacinto.
Nesta dinâmica toponímica, temos um caso de substituição sistemática por imposição do poder econômico, neste caso representado pela direção da empresa Great Western como fator condicionante nesta mudança, como forma de homenagear a figura de Paulo Jacinto Tenório, rico fazendeiro de Quebrangulo que havia doado terras para a passagem da ferrovia.

\section{O2 COITÉ DO NÓIA}

Localização: Mesorregião do Agreste Alagoano; Microrregião de Arapiraca

Topônimo: Coité do Nóia; Taxionomia: Antropotopônimo

Etimologia: Composto de origem indígena tupi: kuieté 'cuia feita de coco cortado ao meio' ++ prep. lat. de + noia (não identificado)

Estrutura Morfológica: elemento composto híbrido: morfema lexical Coite (nome atemático) + forma dependente $d e+o=d o+$ morfema lexical noi- + morfema classificatório vogal temática $-a$

Informações Enciclopédicas: Os pioneiros do lugar pertenciam à família Nóia e lá havia pequenas árvores que dão fruto, o coité, o qual, aberto ao meio, é usado como cuia para beber água, medir farinha ou outros cereais. O povo colhia os frutos na propriedade dos Nóia, popularizando assim a localidade com tal denominação. A família Nóia, pioneira daquela região, era proprietária das primeiras quatro casas que lá existiam, pelos idos de 1880, conforme depoimento do mais antigo morador da cidade. Manoel Jô da Costa, oriundo de Limoeiro de Anadia, fixou-se naquela área pouco tempo depois, dedicando-se à agricultura e à atividade pastoril. Um intercâmbio maior entre o povoado e as cidades vizinhas, proporcionado pela abertura de novas estradas, contribuiu decisivamente para que Coité do Nóia passasse a ocupar lugar de destaque na região. Tal fato determinou a sua elevação 
à categoria de município autônomo, através da Lei n 2.616, datada de 21 de agosto de 1963. Desmembrado de Limoeiro de Anadia, teve sua instalação oficial em 24 de setembro de 1963. Fonte: www.wikialagoas.al.org.br

\section{O3 GIRAU DO PONCIANO}

Localização: Mesorregião do Agreste Alagoano; Microrregião de Arapiraca Topônimo: Girau do Ponciano; Taxionomia: Antropotopônimo

Etimologia: composto greco-latino de origem latina: gyrus derivado de giro 'significa tipo de armadilha para caça de animais' + + prep. lat. de do greg. poncio

Estrutura Morfológica: elemento composto híbrido: morfema lexical girau (nome atemático) + forma dependente $d e+o=d o+$ morfema lexical porci- + morfema derivacional $-a n o$ Informações Enciclopédicas: Um dos primeiros proprietários do lugar chamava-se Ponciano. Ele para facilitar sua atividade de caçador construiu um jirau, pequena armação de madeira onde ficavam os animais abatidos. Daí o antropotopônimo Girau do Ponciano. Sendo assim, o designativo do povoamento se deve a um caçador de nome Ponciano que, acompanhado de dois companheiros, instalou um jirau para suas caçadas, aproveitando a caça abundante. Logo se fundou a primeira propriedade. Foi rápido o progresso de Belo Horizonte, primeiro nome do lugarejo. Pelo decreto-lei estadual $n^{\circ} 2909$, de 30 de dezembro de 1943, o distrito de Belo Horizonte passou a denominar-se Ponciano. Elevado à categoria de município com a denominação Girau do Ponciano pela lei estadual $n^{\circ} 2101$, de 15 de julho de 1958, desmembrado de Traipu

Fonte: www.wikialagoas.al.org.br

O4 MINADOR DO NEGRÃO

Localização: Mesorregião do Agreste Alagoano; Microrregião de Palmeira dos Índios Topônimo: Minador do Negrão; Taxionomia: Antropotopônimo

Etimologia: do francês mine, 'manancial de riqueza' + prep. lat. de + adj. lat. niger, nigra, nigrum, 'preto'.

Estrutura Morfológica: elemento composto híbrido: morfema lexical min-+ morfema classificatório vogal temática $-a+$ morfema derivacional $-d o r+$ forma dependente $d e+o=d o+$ morfema lexical negr- + morfema derivacional -ão

Informações Enciclopédicas: $\mathrm{O}$ antropotopônimo de Minador do Negrão teve origem no fato de existir na propriedade de Félix Negrão, considerado o fundador da cidade, uma fonte de água cristalina de ótima qualidade e grande potencial. O município deve sua criação e povoamento a uma fazenda de gado que fora instalada em 1936 por Félix de Souza Negrão. É bem verdade que antes dessa época, já deveriam existir moradores em regiões próximas. Em 1940 foi criada uma feira livre, onde pessoas e comerciantes de outras regiões vinham para comprar e negociar. Em 1950 foi elevada à condição de vila, já que o progresso da 
povoação que ali se formava era uma constante. Sempre pertenceu a Palmeira dos Índios, de onde foi emancipado. Tornou-se município através da Lei $n^{\circ} 2470$ de 27 de agosto de 1962 , ocorrendo sua instalação oficial a 9 de setembro do mesmo ano, com o território formado por apenas um distrito, o da sede, situação que ainda hoje perdura.

Fonte: www.wikialagoas.al.org.br

Nos casos (2), (3) e (4), temos antropotopônimos formados por estruturas mórficas compostas, nesses sintagmas toponímicos, o segundo elemento linguístico exerce uma função restritiva e ligam-se ao primeiro de forma mediata.

Eles são constituídos por apelidos ou sobrenomes de família, homenageando donos de terras da região que tinham ligação com o local a ser nomeado.

Acreditamos que esses antropotopônimos refletem a forma encontrada pelos denominadores para distinguir pessoas e/ou famílias de destaque destas comunidades e estão relacionados ao anseio do denominador de reverenciar alguém representativo do poder econômico em uma destas localidades ao longo do tempo, sendo o nome o meio utilizado para perpetuar tal ato.

\subsection{Mesorregião do Leste Alagoano}

Na Mesorregião do Leste Alagoano, registramos 6 (seis) antropotopônimos. A saber: (5) Marechal Deodoro, (6) Colônia Leopoldina, (7) Joaquim Gomes, (8) Teotônio Vilela, (9) Anadia e (10) Atalaia na função onomástica de nomear de municípios.

\section{O5 MARECHAL DEODORO}

Localização: Mesorregião do Leste Alagoano; Microrregião de Maceió

Topônimo: Marechal Deodoro, Taxionomia: Axiotopônimo

Etimologia: do francês. maréchal, 'posto superior no exército' + do latim Deo, 'Deus'.

Estrutura Morfológica: elemento específico híbrido: morfema lexical marechal (nome atemático) + morfema lexical deodor- + morfema classificatório vogal temática -o

Informações Enciclopédicas: A cidade de Marechal Deodoro é um dos sítios históricos mais importantes do Estado de Alagoas. Em 1591, já estava consolidado o seu núcleo urbano inicial, conquistado dos Caetés. Foi a primeira capital de Alagoas. O nome da cidade é uma homenagem ao proclamador da República brasileira Marechal Deodoro da Fonseca. Após a instalação do novo regime, em 15 de novembro de 1889, a velha Alagoas passou a ter a atual denominação. Antes era conhecida como Vila da Santa Maria Madalena da Lagoa do Sul, ou simplesmente, Madalena. O município foi criado em 1636, em 1817 passou a capital da capitania de Alagoas, criada nesse ano, sendo o nome da vila alterado para Alagoas. Em 1823 foi elevada a cidade. A capital da província de Alagoas passou para Maceió em 1839. O nome 
da cidade foi alterado para o atual no ano de 1939, em homenagem ao Marechal Deodoro da Fonseca, alagoano que foi o primeiro presidente da república do Brasil. Em 16 de setembro de 2006, dia da emancipação política de Alagoas, foi considerada pelo Ministério da Cultura como Patrimônio Histórico Nacional.

Fonte: www.wikialagoas.al.org.br

Neste caso (5), temos um dos poucos casos de axiotopônimo registrado na toponímia alagoana, designando um município da Microrregião de Maceió. Esse designativo municipal revela a materialização de um discurso de nacionalidade, socialmente constitutivo, no qual sua escolha está intrinsicamente ligada ao proclamador da República brasileira Marechal Deodoro da Fonseca um militar de alta patente.

06 COLÔNIA LEOPOLDINA

Localização: Mesorregião do Leste Alagoano; Microrregião de Mata Alagoana

Topônimo: Colônia Leopoldina. Taxionomia: Antropotopônimo

Etimologia: composto latino de colonia, -ae e significa 'grupo de migrante, possessão, domínio'. + leopodina.

Estrutura Morfológica: elemento específico composto: morfema lexical coloni-+ morfema classificatório vogal temática $-a+$ morfema lexical leopoldina

Informações Enciclopédicas: Nasceu com a criação, pelo Governo Imperial, de uma colônia militar, em 20 de fevereiro de 1852, para combater os remanescentes dos revoltosos cabanos e papa-méis, instalados na densa mata do território que ia de Maragogi a Porto Calvo. A derrota dos rebeldes terminou com o posto militar avançado, em 1867, mas o povoado que se havia formado em torno dele, consolidou-se. O Imperador D. Pedro II visitou o lugar em 1860. Em vista disso, a antiga colônia homenageou a Imperatriz Dona Leopoldina, mãe do monarca. A Lei 372, de 1861, criou o distrito de Leopoldina e uma outra lei, em 1901, elevou-o à vila e depois município. Isso contribuiu para que a antiga colônia voltasse a progredir. Em 1923, passou à condição de cidade.

Fonte: www.wikialagoas.al.org.br

Neste caso (6), temos um dos raros casos de registro de antropotopônimo feminino: Colônia Leopoldina no léxico onomástico-toponímico municipal do Estado em homenagem à Imperatriz Dona Leopoldina, mãe de D. Pedro II.
É relevante destacar que, quanto à categoria de gênero, os antropotopônimos masculinos são bem mais produtivos lexicalmente do que os nomes individuais femininos. Atestando a presença de um discurso de 
natureza ideológica machista, materializado no léxico da língua.

Atribuímos essa fecundidade linguística ao fato de as mulheres, historicamente, não exerciam atividades de destaque na sociedade, uma vez que durante séculos a sociedade brasileira seguiu um sistema patriarcal.

O7 JOAQUIM GOMES

Localização: Mesorregião do Leste Alagoano; Microrregião de Mata Alagoana

Topônimo: Joaquim Gomes; Taxionomia: Antropotopônimo

Etimologia: Composto de origem hebraico: Yhoyaquim 'o que Deus elevou', + Gomos orius 'o homem de guerra'.

Estrutura Morfológica: elemento específico composto: morfema lexical joaquim (nome atemático) + morfemas lexical gomes

Informações Enciclopédicas: Anteriormente, era uma pequena aldeia Urupê, chamada pelos índios de Urucum, que é o fruto do urucuzeiro uma substância que se extrai da polpa desse arbusto e é empregada na fabricação do colorau. O município de Joaquim Gomes tem suas origens históricas ao engenho São Salvador, de propriedade de José Correia de Araújo Barros. Em 1900, Araújo Barros faleceu. Por razões de problemas financeiros que envolveram os seus negócios a sua propriedade ficou alienada a seu genro, Joaquim Gomes da Silva Rego, que tinha a patente de major da Guarda Nacional, resolveu tomar a frente dos negócios da família e adquiriu do banco credor a propriedade então alienada. Graças ao espírito empreendedor de Joaquim Gomes, o local alcançou notável prosperidade. A Pequena vila que se formou viveu uma fase de grande desenvolvimento tal fato ensejou o surgimento de movimentos para conseguir sua emancipação política.

Fonte: www.wikialagoas.al.org.br

O8 TEOTÔNIO VILELA

Localização: Mesorregião do Leste Alagoano; Microrregião de São Miguel dos Campos Topônimo: Teotônio Vilela; Taxionomia: Antropotopônimo

Etimologia: Composto de origem latina:

Estrutura Morfológica: elemento específico composto: morfemas lexicais teotonio + vilela Informações Enciclopédicas: Antiga Feira Nova, o povoado começou a ser formado na década de 50 do século XX em função de uma ponte construída sobre o Rio Coruripe, nas imediações do Engenho São Mateus, propriedade do senhor Samuel Pereira Sampaio. À época, fazia parte do município de Junqueiro. No início da década de 70, o empresário Teotônio Vilela comprou parte da propriedade. A partir daí, a povoação cresceu e passou a atrair novos moradores. Em suas terras se localiza a Usina Seresta, empresa de propriedade da família Vilela. Quando do falecimento de Teotônio Vilela, seu nome foi dado ao município, uma homenagem à sua condição de destacado porta-voz das aspirações nacionais pela 
democracia na campanha pelo retorno das eleições diretas no Brasil, fato que apressou o fim do regime militar instaurado em 1964. Teotônio Vilela recebeu o epíteto de "Menestrel das Alagoas". Em 1982, a vila elegeu três vereadores, que começaram de imediato o movimento pela autonomia. Através de plebiscito, Feira Nova decidiu pela emancipação política, com o nome alterado para Teotônio Vilela. O município foi criado em 1986. Somente em novembro de 1988.

Fonte: www.wikialagoas.al.org.br

Nos casos (7) e (8), temos antropotopônimos formados por justaposição de estruturas mórficas compostas, nesses sintagmas toponímicos, o segundo elemento linguístico se une ao primeiro de forma imediata.

Esses antropotopônimos mostram o elo do poder político-econômico com o ato de nomear municípios em Alagoas, suas escolhas homenageiam Joaquim Gomes da Silva Rego, que era empresário e tinha a patente de major da Guarda Nacional e o empresário-usineiro e político Teotônio Vilela, figura de destaque nas aspirações nacionais pela democracia na campanha pelo retorno das eleições diretas no Brasil.

\section{ANADIA}

Localização: Mesorregião do Leste Alagoano; Microrregião de São Miguel dos Campos Topônimo: Anadia; Taxionomia: Antropotopônimo

Etimologia: composto greco-latino do gr. ana prep. 'que nas derivações funciona como prefixo, valendo como repetição' + dies 'dia'.

Estrutura Morfológica: elemento específico simples: morfema lexical an-+ morfema classificatório vogal temática - $a+$ morfema lexical $d i-+$ morfema classificatório vogal temática - $a$ Informações Enciclopédicas: Até o período holandês, era conhecida como Campo dos Arrozais dos Inhaúns, denominação que abrangia também São Miguel dos Campos e outras localidades vizinhas. Segundo os relatórios flamengos, eram "os mais férteis campos do Brasil”. Foi elevada à Vila em 1799, com a denominação de Vila Nova de São João de Anadia. Em 1801, quando foi elevado à categoria de vila, passou a ser chamada Vila Nova de Anadia, em homenagem ao Visconde de Anadia, ministro português que autorizou a criação da vila. A freguesia foi instalada em 1802. Fez parte da Comarca de Marechal Deodoro até 1833 e a partir desta data, passou para a Comarca de Penedo. Hoje, a cidade tem sua própria comarca. Elevado à condição de cidade com a denominação de Anadia, pela lei estadual $n^{\circ} 86$, de 25-07-1895 e a categoria de município. Pela lei estadual nº 2507, de 01-12-1962.

Fonte: www.wikialagoas.al.org.br 
10 ATALAIA

Localização: Mesorregião do Leste Alagoano; Microrregião de Mata Alagoana Topônimo: Atalaia; Taxionomia: Antropotônimo

Etimologia: Do árabe at-talla' $a(t)$ 'lugar alto'

Estrutura Morfológica: elemento específico simples: morfema lexical atalaia Informações Enciclopédicas: O nome do município foi dado por D. José I em 1764, em homenagem, provavelmente ao Visconde de Atalaia, fidalgo português muito amigo de D. José I. Contribui para isso o fato de que Atalaia começou a ser povoada por volta de 1692, tendo tido como primeiro nome Arraial dos Palmares. Portanto, até o ano de 1764, não há menção nos registros históricos do nome Atalaia. A ocupação das terras onde hoje situa-se o município iniciou-se por volta de 1692 por Domingos Jorge Velho, bandeirante paulista contratado pelo então Governador da Província de Pernambuco Fernão de Souza Carrilho para destruir o Quilombo dos Palmares. Apesar do crescimento da povoação, o Arraial dos Palmares não era reconhecido pelas autoridades. Somente em 12 de março de 1701, o Governador da Província de Pernambuco recebe Carta Régia determinando a criação oficial do arraial, porém com o nome de Arraial de Nossa Senhora das Brotas. No entanto, este nome não caiu no gosto dos habitantes, permanecendo os habitantes utilizando a denominação Arraial dos Palmares. Somente em 1716, os filhos e a esposa de Domingos Jorge Velho recebem o decreto que doa a sesmaria onde hoje localiza-se Atalaia, como recompensa pela destruição dos Palmares. D. José I atendendo em parte às reivindicações da população, elevou o Arraial dos Palmares à categoria de vila, porém, com o nome de Vila de Atalaia, em homenagem ao Conde de Atalaia, seu amigo particular. Este decreto data de 1 de fevereiro de 1764, considerada a data de sua fundação. Foi a quarta vila criada em Alagoas, depois de Porto Calvo, Marechal Deodoro (antiga Alagoas) e Penedo.

Fonte: www.wikialagoas.al.org.br

Nos casos (9) e (10), temos antropotopônimos formados por estruturas mórficas simples.

Esses nomes próprios de pessoa, Anadia e Atalaia, foram dados em homenagem ao Visconde de Anadia, ministro português que autorizou a criação da vila e ao Visconde de Atalaia, fidalgo português muito amigo de D. José I, respectivamente. Revelando assim, características ideológicas, políticos, culturais e históricos na prática de nomeação.
2.3 Na Mesorregião do Sertão
Alagohono

Na Mesorregião do Sertão Alagoano, registramos 4 (quatro) antropotopônimos. A saber: (11) Delmiro Gouveia; (12) Olho D’água do Casado, (13) Monteirópolis e (14) Major Isidoro na função onomástica de nomear de municípios. 


\section{DELMIRO GOUVEIA}

Localização: Mesorregião do Sertão Alagoano; Microrregião da Alagoana do Sertão do São Francisco

Topônimo: Delmiro Gouveia; Taxionomia: Antropotopônimo

Etimologia: composto de origem latina.

Estrutura Morfológica: elemento específico composto: morfemas lexicais delmiro + gouveia. Informações Enciclopédicas: O nome do município é uma homenagem à figura do empreendedor Delmiro Gouveia, que no início do século XX desbravou o território inóspito, trazendo o progresso para a região com suas atividades comerciais e industriais e a instalação de uma vila operária. Foi o responsável, também, pela implantação no local da primeira hidrelétrica da América do Sul. Antes do antropotopônimo Delmiro Gouveia, o lugar chamava-se Pedra, devido à grande quantidade desse mineral no solo da região. $\mathrm{O}$ povoado se constituiu a partir de uma estação da estrada de ferro da então Great-Western. As terras do atual município de Delmiro Gouveia, somadas às de Mata Grande, Piranhas e Água Branca, faziam parte das sesmarias que foram levadas a leilão, em Recife, no ano de 1769. Em $1^{\circ}$ de novembro de 1938, o decreto-lei 846 criou o distrito com o nome Pedra. Foi denominado de Delmiro Gouveia posteriormente, em consequência do Decreto n ${ }^{\circ} 2.909$, de 30 de dezembro de 1943. Desmembrado de Pão de Açúcar, conseguiu sua emancipação política quando foi criado o município pela Lei 1.623, de 16 de junho de 1952, tendo sido instalado apenas em 14 de fevereiro de 1954.

Fonte: www.wikialagoas.al.org.br

Neste caso (11), temos o antropotopônimo Delmiro Gouveia, designando um município da Microrregião da Alagoana do Sertão do São Francisco, sua motivação é oriunda de uma figura ilustre da localidade, formado pelo processo lexical de composição por justaposição e constituindo um elemento específico composto.
Essa unidade lexical se reveste de função onomástica e passa de signo linguístico a signo toponímico, designando um acidente humano. Em outras palavras, passa do significado lexical para o significado onomástico marcado pelas relações sócio-políticas e ideológicas da região.

\section{OLHO D’ÁGUA DO CASADO}

Localização: Mesorregião do Sertão Alagoano; Microrregião da Alagoana do Sertão do São Francisco

Topônimo: Olho D’água do Casado; Taxionomia: Antropotopônimo Etimologia: composto de origem latina: oculus, $-i$ 'olho'+ prep. de $+a q u a$, -ae 'água' + prep. de + casa, -ae 'morada'. 
Estrutura Morfológica: elemento específico composto: morfema lexical olh- + morfema classificatório vogal temática $-0+$ forma dependente $d$ ' (forma apocopada) + morfema lexical $a q u-+$ morfema classificatório vogal temática $-a+$ forma dependente $d e+0=d 0+$ morfema lexical cas- + morfema derivacional -ado

Informações Enciclopédicas: Em 1877, por ocasião da construção do ramal ferroviário da Great Western, os trabalhadores montaram o acampamento próximo ao lugar onde havia nascentes e onde buscavam água. Como aquelas terras pertenciam à propriedade do Sr. Francisco Casado, deram-lhe o nome de Olho d’Água do Casado. Até 1870 só existia na região a fazenda do agricultor Francisco Casado de Melo, onde hoje está a sede da prefeitura. Com o progresso veio o movimento pela emancipação. Em 1962, Olho D’água do Casado se tornou município, através da Lei 2.459, desmembrado de Piranhas. Sede no atual distrito de Olho D’àgua do Casado ex-Olhos da Água Casado. Constituído do distrito sede. Em divisão territorial datada de 31-XII-1963, o município é constituído do distrito sede. Assim permanecendo em divisão territorial datada de 2007. Ratificação da Grafia Olhos D'Água do Casado para Olho D’Água do Casado alterado, pela lei estadual nº 2962, de 22-08-1962. Fonte: www.wikialagoas.al.org.br

Neste caso (12), temos uma forma parental nomeando município, homenageando uma personalidade local de destaque por meio do sobrenome de família: Casado em homenagem ao fazendeiro Francisco Casado de Melo

\section{MONTEIRÓPOLIS}

Localização: Mesorregião do Sertão Alagoano; Microrregião de Batalha

Topônimo: Monteirópolis; Taxionomia: Antropotopônimo

Etimologia: Composto de origem greco-romanoo lat. mons 'monte' + do gr. Tó גıs, pólis 'cidade'

Estrutura Morfológica: elemento específico híbrido: morfema lexical mont- + morfema derivacional -eiro + morfemas lexical polis

Informações Enciclopédicas: Antes de denominar-se Monteirópolis, o local era conhecido como Guaribas, palavra de origem tupi que serve para designar certo gênero de macaco da América ou uma espécie de periquito. Não consta nos anais o motivo da utilização desse nome naquelas plagas sertanejas, em épocas mais remotas. Monteirópolis foi um nome escolhido para homenagear um de seus grandes benfeitores e fundador. Por volta de 1870, os únicos moradores da região eram José Domingos Monteiro, Antônio Prudente, Pacífico de Albuquerque, Manoel Mingote e Manoel Antônio Barbosa. São eles considerados os primeiros habitantes e, consequentemente, os fundadores. O desenvolvimento de Monteirópolis somente alcançou fase áurea após 1902 com a chegada de novos habitantes. 
Foi devido o progresso pelo qual estava atravessando a povoação que os homens responsáveis pela comunidade iniciaram a luta pela sua emancipação política. A Lei $\mathrm{n}^{\circ} 2.250$, de 15 de junho de 1960, concedeu autonomia administrativa a Guaribas, mudando-lhe o nome para Monteirópolis, com o território desmembrado de Pão de Açúcar. A instalação oficial do município ocorreu em 13 de agosto do mesmo ano.

Fonte: http://www.wikialagoas.al.org.br

Neste caso (13), temos um antropotopônimo nomeando um município na
Microrregião de Batalha, homenageando um de seus fundadores José Domingos Monteiro.

\section{MAJOR ISIDORO}

Localização: Mesorregião do Sertão Alagoano; Microrregião de Batalha

Topônimo: Major Isidoro; Taxionomia: Axiotopônimo

Etimologia: Composto latino: major, -oris 'comparativo regular de grande; 'militar entre capitão e tenente-coronel' + izare 'com sentido fictitivo'.

Estrutura Morfológica: elemento específico composto: morfemas lexicais major (nome atemático)+ Isidoro

Informações Enciclopédicas: Antigo distrito de Sertãozinho, o município recebeu o seu atual nome em homenagem ao Major Isidoro Jerônimo da Rocha, fundador do povoado. A colonização começou quando Antônio Jerônimo da Rocha comprou uma propriedade na região e se instalou com a sua família. Dos filhos, apenas Isidoro manteve os negócios do pai, que era conhecido como patriarca de Sertãozinho nome de uma de suas fazendas. Isidoro lutou insistentemente pela emancipação. Em 1920, conseguiu que o Poder Legislativo, através da Lei $n^{\circ} 946$, autorizasse o governo a elevar Sertãozinho a município. O governador não aceitou e manteve a área como distrito. Só em 1949 foi concebida a emancipação, desmembrando Sertãozinho dos municípios de Batalha, Santana do Ipanema e Palmeira dos Índios. Nessa época, Isidoro já estava morto, mas os moradores decidiram fazer-lhe a homenagem, dando seu nome à cidade.

Fonte: http://www.wikialagoas.al.org.br

Neste caso (14), temos um axiotopônimo designando um município da Microrregião de Batalha. Esse designativo revela, mais uma vez, a materialização de um discurso de nacionalidade, no qual sua escolha está intrinsicamente ligada em homenagem ao
Major Isidoro Jerônimo da Rocha, fundador do povoado. Neste designativo, enfatiza-se a patente militar constitutiva desse sintagma toponímico. 


\section{CONSIDERAÇÕES FINAIS}

Iniciamos estas considerações finais, enfatizando que é impossível abstrairmos a análise antroponímica das relações de poder. Dessa forma, o presente artigo revela o quanto os nomes próprios de lugares, enquanto objeto simbólico, produzem efeitos de sentidos e são investidos de significância para os sujeitos e pelos sujeitos.

Weber (1991, p. 33) apresenta um clássico conceito de poder ao asseverar que "poder significa toda probabilidade de impor a vontade numa relação social, mesmo contra resistências, seja qual for o fundamento dessa probabilidade". Logo, percebemos que, no ato de nomear municípios alagoanos, identificamos a materialização do poder por intermédio da linguagem.

A relação simbólica entre toponímia e estrutura dominante de poder é representada, no caso dos antropotopônimos, pela homenagem a personalidades detentores do poder secular em Alagoas formadoras do pensamento político e cultural do país, geralmente integrantes da classe dominante, e no caso dos axiotopônimos, pela escolha de nomes próprios individuais de personalidades de relevo, seguida de seus respectivos títulos.

Estas escolhas de um nome para designar acidentes humanos (municípios, distritos e povoados) em Alagoas estão ligadas determinadas motivações refletidas no signo toponímico por meio de relações associativas feitas pelo denominador.

No léxico toponímico municipal alagoano, identificamos topônimos constituídos por nomes próprios individuais e topônimos constituídos por títulos, seguidos de nomes próprios individuais designativos de cidades nas seguintes áreas: 5 (cinco) na mesorregião do Agreste Alagoano: Paulo Jacinto, Minador do Negrão, Girau do Ponciano, Coité do Nóia e Limoeiro de Anadia; 6 (seis) na mesorregião do Leste Alagoano: Marechal Deodoro, Colônia Leopoldina, Joaquim Gomes, Teotônio Vilela, Anadia e Atalaia; 4 (quatro) na mesorregião do Sertão Alagoano: Delmiro Gouveia, Olho D’água do Casado, Monteirópolis e Major Isidoro.

Nestes antropotopônimos e axiotopônimos, o discurso de nacionalidade, juntamente, com o discurso do memorável está bastante marcante, refletindo traços da economia e da política local.

Outra questão interessante a ser observada nesta microtoponímia diz respeito à categoria de gênero. Nesse sentido, os dados aqui analisados mostraram a valorização de nomes individuais masculinos em detrimento aos femininos, expressando o pensamento vigente na sociedade, que normalmente ainda atribui à figura feminina um papel secundário em muitas instâncias da vida social, profissional e familiar.

Registramos, apenas, 2 (dois) antropotopônimos femininos no léxico toponímico estudado: Colônia Leopoldina e Anadia, atestando que as mulheres, geralmente, não são homenageadas com nome de municípios em Alagoas.

Quantitativamente foram detectados 14 (catorze) nomes próprios individuais, refletindo homenagens explícitas ao poder político-econômico e estão representados em todas as mesorregiões do Estado, sendo 12 (doze) antropotopônimos e 2 (dois) axiotopônimos, perfazendo um total de aproximadamente $85,8 \%$ de ocorrência daqueles em 
relação a 14,8\% destes, demonstrando que no léxico toponímico municipal alagoano há uma preferência do nomeador, na categoria dos nomes próprios de pessoa, para eleição de antropotopônimos no ato de nomear cidades alagoanas.

E ainda, é especialmente significativo afirmarmos que não registramos antropotopônimos e axiotopônimos na designação de municípios na microrregião de Traipu, localizada na mesorregião do Agreste Alagoano; nas microrregiões do Litoral Norte, de Penedo e da Serra dos Quilombos, localizadas na mesorregião do Leste Alagoano; e ainda, na microrregião Serrana do Sertão Alagoano, localizada na mesorregião do Sertão Alagoano.

Por fim, acreditamos que este estudo atestou a relevância das pesquisas toponímicas como forma de resgate de aspectos culturais e ideológicos dos grupos sociais, uma vez que os nomes de lugares evidenciam a realidade do ambiente físico e antropocultural de uma dada região na medida em que revelam características de vegetação, hidrografia, fauna, condições de solo e relevo, como também crenças, ideologias, fatos políticos e históricos. Dessa forma, percebemos o valor patrimonial do topônimo.

\section{REFERÊNCIAS}

BRASIL. Ministério do Planejamento, Orçamento e Gestão. Instituto Brasileiro de Geografia e Estatística (IBGE). Disponível em http://www.ibge.gov.br/. Acesso em 31 abr. 2014. CAMPS IGLESIAS, A.; NOROÑA VILÁ, M. T. Aproximación al estudio de la toponimia cubana. La Habana: Academia de Ciencias de Cuba, Instituto de Literatura y Lingüística, s.d.
CARVALHINHOS, P. J. Interface onomástica / literatura: a toponímia, o espaço e o resgate de memória na obra de memórias da rua do ouvidor de Joaquim Manuel de Macedo. In.: Cadernos do CNLF. Rio de Janeiro : CIFEFIL, v. 12, n. 10, p. 83-99. 2009.

DAUZAT, A. Les noms de Lieux: Origene et évolution. Paris: Librairie Delagrave, 1926.

DICK, M.V.de P. do A. A motivação toponímica: princípios teóricos e modelos taxeonômicos. São Paulo, SP. Tese (Doutorado). Universidade de São Paulo - USP, 1980, 198 p.

A motivação toponímica e a realidade brasileira. São Paulo : Edições Arquivo do Estado, 1990.

Acta Semiotica et Lingvistica. Sociedade Brasileira dos Professores de Linguística. São Paulo: Universidade de Braz Cubas, 1995, v. 8, p. 97-122.

KATAMBA, F. Morphology. Houndmills: The Macmillan Press, 1993.

. Toponímia indígena: um estudo lexical dos nomes de municípios alagoanos de étimo tupi. In.: Veredas Favip, . v. 6, n. 1, jan.-jun., p. 161-179, 2013.

ROSTAING, C. Les noms de Lieux. Paris: Presses Universitaires de France, 1961.

SALAZAR-QUIJADA, A. La toponimia en Venezuela. Caracas: Universidad Central de Venezuela, 1985.

SEABRA, M. C. T. C. de (org.). o léxico em estudo. Belo Horizonte: faculdade de Letras da UFMG, 2006.

WEBER, M. A objetividade do conhecimento nas ciências sociais. In: COHN, G. (Org.) Max Weber. 4. ed. São Paulo: Ática, 1991. p. 79-127.

Recebido para publicação em 22 jun. 2014 Aceito para publicação em 10 out. 2014. 